\title{
MOLECULAR MARKERS OF GENETIC VARIABILITY IN TRITICALE VARIETIES REGISTERED IN THE CZECH REPUBLIC
}

\author{
T. Vyhnánek, J. Bednár
}

Received: March 23, 2006

\begin{abstract}
VYHNÁNEK, T., BEDNÁŘ, J.: Molecular markers of genetic variability in triticale varieties registered in the Czech Republic. Acta univ. agric. et silvic. Mendel. Brun., 2006, LIV, No. 5, pp. 149-154

Genetic variability was detected in 15 varieties of triticale (XTriticosecale Wittmack., 2n $=6 \mathrm{x}=42$, BBAARR) registered in the Czech Republic by means of polymorphism of DNA using the RAPD method and the SSR method. For detection we used 80 RAPD primers. The lower reproducibility of the RAPD markers was resolved by means of repeated analyses (3-4 times). On the basis of statistical evaluation a dendrogram was set up, which allows highly significantly to differentiate the varieties Kolor, Modus and Tornado. The remaining 12 analysed varieties formed 4 clusters. In addition to the RAPD markers a protocol of detection of DNA polymorphism was elaborated and optimised with microsatellite (SSR) markers. For the analyses we used 2 SSR markers (1A chromosome [Xpsp2999] and 1B chromosome [Xpsp3000]), which have been discovered in wheat (T. aestivum L.). Basing on these two SSR markers the only variety Triamant was distinguished from the clusters of the other analysed varieties.
\end{abstract}

triticale, XTriticosecale Wittmack., DNA markers, RAPD, SSR

Triticale (XTriticosecale Wittmack.) is an autogamous plant with a low share of cross-pollination (4$5 \%$ ). This means that the majority of varieties are of the line type or a mixture of isogenic lines (Chloupek, 2000). A number of methods are now available for the detection of the genetic variability (diversity), e.g. morphological characteristics; analysis of pedigrees; biochemical markers, particularly proteins and their various isoenzyme variants; molecular (DNA) markers etc.

The aim of this work was to evaluate the genetic diversity within 15 registered varieties of triticale (XTriticosecale Wittmack., $2 \mathrm{n}=6 \mathrm{x}=42$ ) by RAPD and SSR markers.

\section{MATERIAL AND METHODS}

The polymorphism of DNA was analysed in 13 winter forms and two spring forms of triticale varieties registered in the Czech Republic (Tab. I). Mixed samples of certified seeds from the 2002 and 2003 harvests were obtained from the Central Institute for Supervising and Testing in Agriculture, testing station in Hradec nad Svitavou.

Genomic DNA was isolated from young plants (6 days old) using the Dneasy Plant Mini Kit isolation kit (Qiagen, GE). The DNA concentration was assessed on a spectrophotometer. 
I: Analysed triticale varieties

\begin{tabular}{|c|c|c|c|}
\hline \multicolumn{2}{|c|}{ Variety } & Year of registration & Property \\
\hline \multirow{2}{*}{ spring } & Gabo & 1999 & Hodowla Roslin Strzelce, Sp. z o. o., Poland \\
\hline & Legalo & 2004 & DANKO Hodowla Roslin, Sp. z o. o., Poland \\
\hline \multirow{13}{*}{ winter } & Disco & 1997 & DANKO Hodowla Roslin, Sp. z o. o., Poland \\
\hline & Lamberto & 2003 & DANKO Hodowla Roslin, Sp. z o. o., Poland \\
\hline & Lupus & 2003 & NORDSAAT Saatzuchtgesellschaft mbH, Germany \\
\hline & Kitaro & 2003 & DANKO Hodowla Roslin, Sp. z o. o., Poland \\
\hline & Kolor & 1996 & SELGEN, a. s., Czech Republic \\
\hline & Marko & 2001 & Hodowla Roslin Strzelce, Sp. z o. o., Poland \\
\hline & Modus & 1998 & NORDSAAT Saatzuchtgesellschaft mbH, Germany \\
\hline & Presto & 1990 & DANKO Hodowla Roslin, Sp. z o. o., Poland \\
\hline & Sekundo & 2000 & Hodowla Roslin Szelejewo, Sp. z o. o., Poland \\
\hline & Ticino & 2003 & Pflanzenzucht Saka GbR, Germany \\
\hline & Tornado & 1996 & Hodowla Roslin Strzelce, Sp. z o. o., Poland \\
\hline & Triamant & 2004 & Lochow-Petkus GmbH, Germany \\
\hline & Tricolor & 2002 & Florimond Desprez, France \\
\hline
\end{tabular}

\section{RAPD (Random Amplified Polymorphic DNA) analysis:}

We analysed 80 RAPD primers chosen in accordance with literature. The reaction mixture for PCR, total volume $25 \mu \mathrm{l}$ contained $0.4 \mathrm{U}$ Taq polymerase (Finnzyme), $1 \times$ aliquot buffer (Finnzyme), $0.25 \mathrm{mM}$ of each dNTP (Promega), $20 \mathrm{ng}$ of primer and $25 \mathrm{ng}$ of template DNA. The reaction conditions of PCR in
T3 cycler (Biometra) - initial denaturation 1 min. at $94{ }^{\circ} \mathrm{C}$, then 45 cycles - denaturation $1 \mathrm{~min}$. at $94{ }^{\circ} \mathrm{C}$, annealing $2 \mathrm{~min}$. at $35^{\circ} \mathrm{C}$, extension $1 \mathrm{~min}$. at $72^{\circ} \mathrm{C}$. A final extension step at $72{ }^{\circ} \mathrm{C}$ for $10 \mathrm{~min}$. followed. Electrophoretic separation was carried out on $1.5 \%$ agarose gel and visualization using ethidium bromide (Fig. 1). The lower reproducibility of the RAPD markers was resolved by means of repeated analyses (3-4 times).

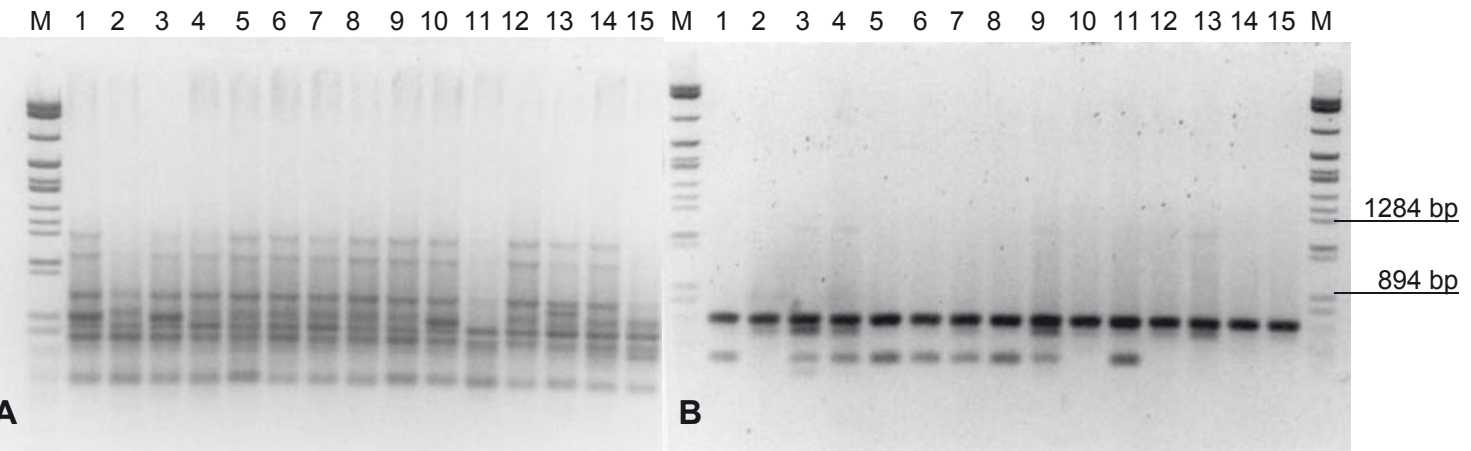

1: RAPD patterns of 15 triticale genotypes obtained with different primers

A) primer OPF13; B) primer BC628

M - DNA size marker ( $\lambda$ DNA Eco471 /AvaII/, MBI Fermentas); 1 - Presto; 2 - Kolor; 3 - Disco; 4 - Modus; 5 - Sekundo; 6 - Marko; 7 - Tricolor; 8 - Kitaro; 9 - Lamberto; 10 - Ticino; 11 - Gabo; 12 - Lupus; 13 - Tornado; 14 - Triamant; 15 - Legalo

\section{SSR (Simple Sequence Repeats) analysis:}

We analysed 2 SSR markers (Devos et al., 1995). The reaction mixture for PCR, total volume $25 \mu 1$ con- tained $0.5 \mathrm{U}$ Taq polymerase (Promega), $1 \times$ aliquot buffer, $0.1 \mathrm{mM}$ of each dNTP (Promega), $0.3 \mathrm{M}$ of each primer and $30 \mathrm{ng}$ of template DNA. The reacti- 
on conditions of PCR in T3 cycler (Biometra) - initial denaturation $2 \mathrm{~min}$. at $93{ }^{\circ} \mathrm{C}$, then 30 cycles - denaturation $1 \mathrm{~min}$. at $93{ }^{\circ} \mathrm{C}$, annealing $2 \mathrm{~min}$. at $54{ }^{\circ} \mathrm{C}$, extension $2 \mathrm{~min}$. at $72^{\circ} \mathrm{C}$. The amplification SSR products were visualized on $15 \%$ non-denaturation polyacrylamid gels in TBE buffer $(300 \mathrm{~V})$ followed by colouring with silver (0.2\% $\left.\mathrm{AgNO}_{3}\right)$ (Fig. 2).
The resulting electrophoreograms were converted to binary matrices represented by the presence (1) or absence $(0)$ of resulting alleles and then evaluated by means of statistical software FreeTree version 9.1 using the UPGMA construction method and similarity coefficient according to Jaccard. The software TreeView version 1.6 was used for the graphical expression of the matrix.

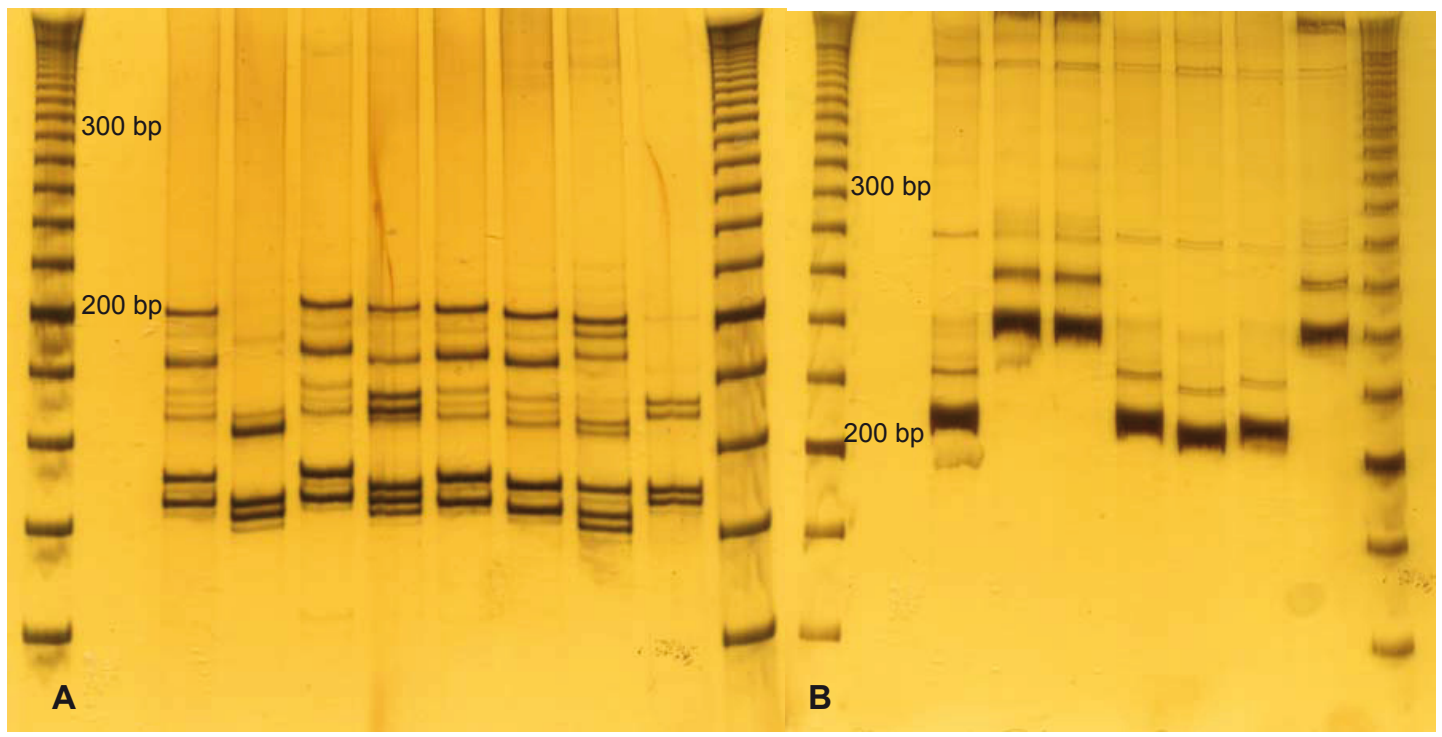

2: SSR patterns of 15 triticale genotypes

A) Xpsp2999 - (from the left) DNA size marker (20 bp extended DNA ladder), negative control, Kitaro, Lamberto, Ticino, Gabo, Lupus, Tornado, Triamant, Legalo, DNA size marker; B) Xpsp3000 - (from the left) DNA size marker, negative control, Presto, Kolor, Disco, Modus, Sekundo, Marko, Tricolor, DNA size marker

\section{RESULTS AND DISCUSSION}

Garg et al. (2001) assessed the RAPD method as the suitable method for mapping the genetic diversity in triticale, second only to the SSR method and better than the AFLP method. In our case the individual RAPD primers resulted in different polymorphism of the obtained DNA products. Out of the 80 RAPD primers used, 8 showed a uniform spectrum of products for all the 15 triticale varieties (Tab. II). The remaining primers highly significantly differentiated the varieties Kolor, Modus and Tornado from the other varieties, which make up four groups (Fig. 3A). One group involves the spring varieties Gabo and Legalo along with the winter varieties Tricolor and Triamant. Since a mixed sample (miniprep) was used, the application of RAPD primers did not make it possible to detect the genetic variability within the individual varieties, unlike prolamine proteins of the triticale kernel (Vyhnánek \& Bednáŕ, 2005).

II: Sequences of the used RAPD primers with a uniform spectrum of products

\begin{tabular}{|c|c|}
\hline Primers & Sequence $\left(5^{\prime} \rightarrow 3^{\prime}\right)$ \\
\hline H12 & TTC CGA ACC C \\
\hline H17 & GGA AAC CCC T \\
\hline H39 & AGC GTG TCT G \\
\hline H47 & CTC TCC GCC A \\
\hline H52 & GAA ACA CCC C \\
\hline H62 & GTG ACA GGC T \\
\hline H82 & TCG CCG CAA A \\
\hline
\end{tabular}


The methods of detection of SSR markers of wheat in triticale were tested. Kuleung et al. (2004) assessed the possibility of use of wheat and rye SSR markers in triticale and confirmed the transferability of $58 \%$ of wheat and $39 \%$ of rye SSR markers into the triticale genome. On the basis of a dendrogram and with the aid of 2 SSR markers we managed highly significantly to differentiate the Trimaran variety and the other analysed varieties (Fig. 3B). On the dendrogram we can see a cluster of spring triticale forms (Gabo and Legalo).

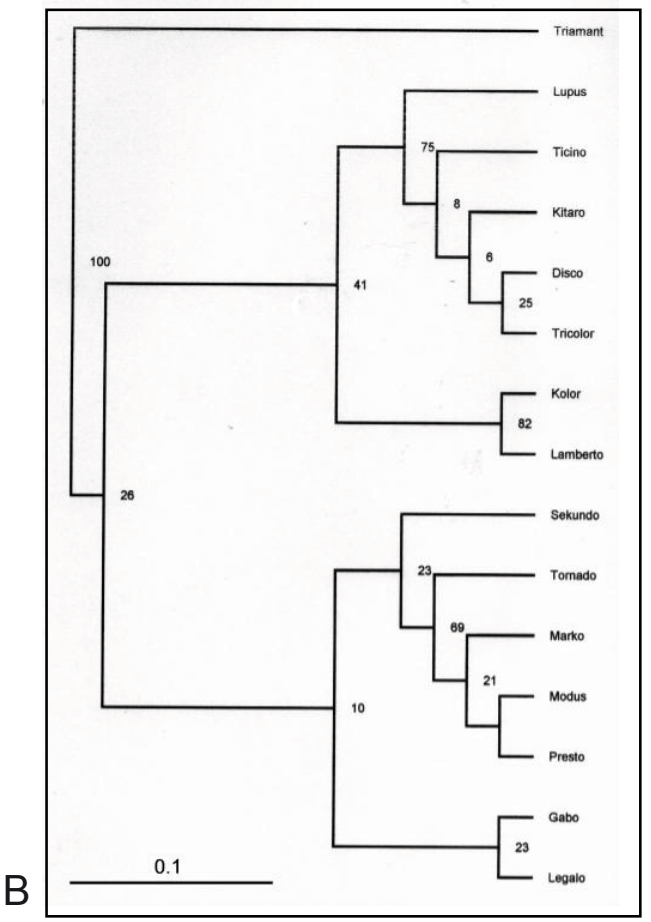

3: Dendrograms of 15 triticale varieties (Jaccard coefficient, $P=99 \%$ )

A) RAPD primers; B) SSR markers

The SSR markers are localised on the short arm of chromosome 1A [Xpsp2999, motive $\left.(\mathrm{CAG})_{5}(\mathrm{CAA})_{8}\right]$ and short arm of chromosome 1B [Xpsp3000, motive (CAA) ${ }_{15}$. Bougot et al. (2002) used the SSR marker Xpsp2999 to distinguish the alleles of Pm3 resistance to Blumeria graminis. Devos et al. (1995) showed the linkage of this marker with LMW glutenins and the gliadin gene Gli 1-1. In our case the products ranged between 140 and $160 \mathrm{bp}$. We detected 4 allele variants. Using this SSR marker in wheat, Manifesto et al. (2001) detected products of similar size (133$157 \mathrm{bp}$ ) and described 11 allele variants incl. the zero allele. The zero allele was not detected in the analysed triticale varieties. Linkage with $\gamma$-gliadins was described in the SSR marker Xpsp3000 (Devos et al., 1995); in linkage with the $\operatorname{Yr} 10_{\text {vav }}$ the product of $285 \mathrm{bp}$ is in relation to yellow rust resistance (Bariana et al., 2002). Manifesto et al. (2001) discovered 13 allele variants in wheat $(213-285 \mathrm{bp})$ including the zero allele. In our varieties the product size ranged between 200 and 260 bp. The 260 bp size allele was detected in the Triamant variety only.

In our experiments better resolution of the varieties by the RAPD method was obtained than using SSR markers. The 72 polymorphic RAPD primers highly significantly differentiated 3 varieties while only one was differentiated by 2 SSR markers. The use of a higher number of SSR markers would probably increase the resolution and the results would be in favour of SSR markers similarly as reported by Garg et al. (2001).

\section{SOUHRN}

Molekulární markery genetické variability u odrůd tritikale registrovaných v České republice Genetická variabilita byla detekována metodami molekulární genetiky (RAPD a SSR) u 15 odrůd tritikale (XTriticosecale Wittmack., 2n =6x =42, BBAARR), které jsou registrovány v České republice. 
Pro detekci polymorfizmu DNA bylo využito 80 RAPD primerů. Nižší reprodukovatelnost RAPD analýz byla kompenzována opakováním analýz (3-4×). Na základě statistického vyhodnocení byl sestaven dendrogram, kde je možno vysoce průkazně odlišit odrůdy Kolor, Modus a Tornado. Zbývajících 12 analyzovaných odrůd tvoří čtyři klastery. Byl optimalizován protokol detekce variability DNA pomocí mikrosatelitních markerů u tritikale. Pro analýzy byly využity dva SSR markery (1A chromozom [Xpsp2999] a 1B chromozom [Xpsp3000]), které byly popsány u pšenice obecné (T. aestivum L.). Na základě použitých dvou SSR markerů se podařilo odlišit odrůdu Triamant od klasterů ostatních analyzovaných odrůd.

tritikale, XTriticosecale Wittmack., DNA markery, RAPD, SSR

\section{ACKNOWLEDGMENT}

Supported by the Czech Science Foundation, project No. 521/03/P173.

\section{REFERENCES}

BARIANA, H. S., BROWN, G. N., AHMED, N. U., KHATKAR, S., CONNER, R. L., WELLINGS, C. R., HALEY, S., SHARP, P. J. and LAROCHE A.: Characterisation of Triticum vavilovii-derived stripe rust resistance using genetic, cytogenetic and molecular analyses and its marker-assisted selection. Theoretical and Applied Genetics, 2002, 104, 2-3: 315-320. ISSN 0040-5752.

BOUGOT, V., LAMOINE, J., PAVOINE, M. T., BARLOY, D. and DOUSSINAULT, G.: Identification of a microsatellite marker associated with $P m 3$ resistance alleles to powdery mildew in wheat. Plant Breeding, 2002, 121, 4: 325-329. ISSN 01799541.

DEVOS, K. M., BRYAN, G. J., COLlinS, A. J., STEPHENSON, P. and GALE, M. D.: Applications of two microsatellite sequences in wheat storage proteins as molecular markers. Theoretical and Applied Genetics, 1995, 90, 2: 247-252. ISSN 0040-5752.

GARG, M., SINGH, S., SINGH, B., SINGH, K. and
DHALIWAL, H. S.: Estimates of genetic similarities and DNA fingerpriting of wheats (Triticum species) and triticale cultivars using molecular markers. Indian Journal of Agricultural Sciences, 2001, 71, 7: 438-433. ISSN 0019-5022.

CHLOUPEK, O.: Genetická diverzita, šlechtění a semenářství. 2. vyd. Praha: Academia. 311 s. ISBN 80-200-0779-2.

KULEUNG, C., BAENZIGER, P. S. and DWEIKAT, I.: Transferability of SSR markers among wheat, rye and triticale. Theoretical and Applied Genetics, 2004, 108: 1147-1150. ISSN 0040-5752.

MANIFESTO, M. M., SCHLATTER, A. R., HOPP, H. E., SUAREZ, E. Y. and DUBCOVSKY, J.: Quantitative evalution of genetic diversity in wheat germplasm using molecular markers. Crop Science, 2001, 41, 3: 682-690. ISSN 1435-0653.

VYHNÁNEK, T. and BEDNÁR̆, J.: Polymorphism of prolamin proteins of the grain of triticale varieties certified in the Czech Republic. Plant, Soil and Environment, 2005, 51, 4: 151-155. ISSN 12141178.

Ing. Tomáš Vyhnánek, Ph.D., Doc. Ing. Jan Bednář, CSc., Ústav biologie rostlin, Mendelova zemědělská a lesnická univerzita v Brně, Zemědělská 1, 61300 Brno, Česká republika, e-mail: vyhnanek@mendelu.cz 
